\section{The United Nations Millennium Development Goals}

The Millennium Development Goals are the social Magn Carta of our time. Our actions must be guided by then Now we must continue working to make them binding..." (H.E. Mr. Joschka FISCHER Deputy Federal Chancellor and Minister for Foreign Affairs for Germany

\section{Introduction}

The Millennium Declaration in September 2000 came at a hard time. The 1990s were a rare decade of turn in development for many areas. More than 50 countrie in the world are more impoverished nowadays than they were in 1990 . The main reasons for the tendency of this bad state of occurrence are the discomfiture of government, and conflicts and diseases with the govern gresome effects of hrough key parts of society. Schools and hospital have lost key staff, and the contagion reduced th attainments of families to feed themselves as young men died at a pace never before seen outside a majo war. The pressing need of globalization has made people become poor as well. The restless quest by lobal capital for the cheapest deal has been met with heavy losses ang the wa. ${ }^{2}$ The eight with heavy losses ang the way are brought to life by stories from individuals an communities from around the world, as well as some of the initiatives they have started. There is in the United Nations Millennium Development Goal a global commitment represented by all nations who signed the Declaration to reduce poverty and improve lives. ${ }^{3}$

"The world did celebrate the arrival of the new century, and people ofll cultures joined in But there are many things to correct. The century just ended was disfigured, time and again, by ruthless conflict. Grinding poverty and striking inequality persists.... Diseases, old and new, threaten to und painstaking progress. Nature's life- sustaining services, on which our species depends for its survival, are being seriously disrupted and degraded by our own every day activities.

The world's people look to their leaders... to identify and act on the major challenges ahead", from "We the People" (UN Secretary General Kofi Annan, 2000)

As a result of Annan's words, the UN Millennium Summit was held in New York in September 2000. In
191 States adopted the UN Millennium Declaraion, which outlines various concerns such as peace, security and development, in areas pertaining to environment, human rights and governance. The declaration stresses the special needs of Africa. I mainstreams interconnected and mutually reinforc ing development goals into a global agenda. This se has come to be known as the Millennium Develop(a) place at the global and country levels.

... .we need to empower each country, at the earliest op portunity, to be able to endogenously generate resource that will fuel the sustainable implementation of the $M D C$ in each Country." (E. Mr. Yoweri Kaguta MUSEVEN President of Uganda)

\section{How to come to the MDG?}

\section{The Background}

The United Nations have sponsored a series of worl summits and global conferences since 1990 with view to laying out a comprehensive rights-based development agenda - which includes issues such as quantitative goals, time-bound targets and numerical indicators.

The general idea is that goals and targets mobilize th national and international partners into action to help forge new alliances for development. Utilizing goals also provide a means for benchmarking and assessing progress in development. Policy reforms, budget reallocations and institutional change often result from discussions centered on time-bound targets. However, less than one-third of developing countries have set specific and quantifiable national targets for reducing poverty.

In September 2000, a total of 191 nations, including 147 heads of State and Government, adopted the Millennium Declaration. The Declaration outines peace, security and development concerns, including the areas of environment, human rights, and governance. The Declaration also stresses the special needs of Africa. The Millennium Declaration mainstreams a set of inter-connected and mutually reinforcing development goals into a global agenda. The International Development Goals (IDGs) and the development goals contained in the Millennium Declaration are similar but also different $t^{5}$.

It is the goal that at the turn of the new millennium, extreme poverty, hunger and disease that kills millions of people each year in the poorest parts of the world will be eradicated. The leaders of 191 nations agreed that together they have the resources and the political will to do so. During September 14-16, 2005, the largest gathering of world leaders met at the UN World Summit to discuss the Millennium Development Goals and what needs to be done to achieve them over the coming ten years. The Millennium Development contains eight Goals and 18 targeted objectives, which are a way for the international community to achieve a better world in our lifetime

The aims seem to be good and laudable as they target the main primary challenges faced by majo portions of populations in developing countries. Their practical realisation remains theoretically feasible, but there is a lack of political will. Moreover it is theoretically possible to implement these goals as they are no overly optimistic but rather basic and do not involve tremendous resources. For some reason, the involved actors - as has always been the case - might render their transformation into additional empty promises.

The MDGs are more practical than ambitious as they adopt a more pragmatic approach of what governments are ready to commit to. In that sense, they are realistic but more should be expected in the area of sustainable development than what is stated in the MDGs. "We are the first generation that can actually end poverty and we are running out of excuses.

\section{Comparison between the IDGs and the} Millennium Declaration ${ }^{8}$

\subsection{The International Development Goals}

The Goal is to implement national strategies for sustainable development by 2005 so as to revers the loss of environmental resources by 2015. It is a goal that those who suffer in extreme poverty will be reduced to half the amount between 1990 and 2015 When it comes to international devepment, it is a goal that every child will be enrolled in school by 015. It is hoped that progress will be made toward gender equality and empowering women by eliminating gender disparities in primary and secondary ducation by 2005. The IDG would like to see infan and child mortality rates reduced by two-thirds between 1990 and 2015. It is also a goal that materna mortality ratios will be decreased by three-quarters between 1990 and 2015. By the year 2015, it is a go that full access will be $p$ reproductive health services. Finally, it is a goal that national strategies for sustainable development will be implemented by 2005 so as to reverse the loss of environmental resources by 2015

2.2 The Millennium Declaration

It is the intention that by the year 2015, the proportion of the world's people whose income is less than one dollar a day and the proportion of people who suffer from hunger will be cut in half. It is also intended that by the same date, the proportion of people who are unable to reach or to afford safe drinking water will be reduced by half. By the same date of 2015 , children everywhere, boys and girls alike, will be able to complete a full course of prim ary schod and the and that gir access to al levels of education. By the same date, the amount of maternal mortality will be reduced by three quarters, and under-five child mortality will be reduced by two thirds, of their current rates. By 2015 they will have halted, and begun to reverse, the spread of HIV/AIDS, the scourge of malaria and other major diseases that afflict humanity. More special assistance will be provided to children orphan by HIV/ AIDS. By 2020 the United Nation wouldike HIV/ achieved a significant improvement in the lives of at least 100 million slum dwellers as proposed in the "Cities Without Slums" initiative

\subsection{Similarity but with some difference}

Baseline year - 1990 or 2000? IDGs use 1990 as a baseline year. There is some discrepancy about the baseline year for the Millennium goals. In two cases - maternal mortality and under-five mortality - the term ",current rates" is used directly specifying a 2000 baseline. For the remainder, the targets are stated in the form of "to halve by 2015..." This would seem to imply a 2000 baseline year of the Millennium Declaration for these two points. After discussions within the UN system and with other partners, the issues have been resolved in favor of 1990 serving as the baseline year.

\subsection{Different wording}

At first glance, some of the Millennium goals appea similar to the IDG wording, but in fact they are quit different. For example, IDGs mention universal primary enrolment; the Millennium Declaration refers to universal completion of primary schooling. This would seem to suggest that the Millennium Declaration is more ambitious than the IDGs.

\subsection{Additions and deletions}

Some of the goals which have been added includ hunger, safe water, gender equality for higher education (not just secondary), HIV/AIDS and othe major diseases, children orphaned by HIV/AIDS and improved lives for slum dwellers. Some of the goals that have been deleted are infant mortality and reproductive health services. Infant mortality is listed as part of the indicator of under-five mortity; whereas reproductive health services are included amongst the list of selected indicators for monitoring the MDGs. 
Beyond those linked to poverty, the Millennium Declaration contains a number of development-related targets (as listed in paragraph 19). For instance environment and governance, featured prominently in other sections.

\section{New steps on the way...}

191 nations in total - 147 heads of State and Government - have pledged to meet eight development goals. All these states have chosen to ratify at least one human rights treaty, which for the most part means 'country ownership' of the relevant provisions and that they all have international legal obligations to implement them. These provisions reinforce and complement the millennium development goals." The Millennium Development Goals allow us to improve our understanding of what needs to be done, while we are confronted with the challenge of designing a strategy and obtaining sufficient resources that would make the achievement of these Goals possible.," ${ }^{10}$ (H.E. Dr. Leonel Fernandez President of the Dominican Republic)

\section{About the goals in general}

As adopted in September 2000, The Millennium Declaration is a global development agenda that comprises a set of mutually reinforcing development goals, targets and indicators, known as the Millennium Development Goals (MDGs). The Millennium Development Goals represent a renewed global effort around: Goal 1: Eradicating Extreme Poverty and Hunger; Goal 2: Achieving Universal Primary Education; Goal 3. Promoting Gender Equality and Empower Wom er Women, Goal 4: Reding Improving Maternal Health; Goal 6: Combating HIV/ AIDS, malaria and other diseases; Goal 7: Ensuring Environmental Sustainability; and Goal 8: Developing a Global Partnership for development. ${ }^{1}$

\section{Who are the actors in this specific field?}

It is not only individuals and extended families, but also the states own international organisations, other states, the private sector, companies and businesses, but also different governmental organisations, ministries and entities that are involved at various levels of responsibility. Still the assistance - whether material technical or financial - of the previously mentioned other actors remains of paramount importance.

There are four core elements for the UNDP's strategy on the MDGs as it takes action at the global and country levels 1) Tracking progress towards the MDG from developing countries MDG reports. 2) Millennium Project $t^{12}$ : a research initiative to provide recommendation on how to make progress on the MDGs. 3) Millennium Campaign ${ }^{13}$ : build global support for the goals and support advocacy and awareness-rising efforts ${ }^{14}$. 4) Operational activities: UN systems support progress of the MDGs at the country level. ${ }^{1 .}$

On a global scale, the UN Secretary-General is to submit an annual report to the General Assembly the MDGs; and also to do so more comprehensively every five years. At the country level, the UN Country Team will support the government in monitoring progress and preparing MDG Reports. ${ }^{16}$

\subsection{Country regional action ${ }^{17}$}

As part of the United Nation's strategy to achieve the Millennium Development Goals by 2015, primary focus has been given to action at the country level. They are seemingly moving from large scale to small scale. The rationale for this lies in moving the Millennium commitments from the global to the local level by giving countries the ability to assess their needs, develop political commitment and mobilize public opinion, defin economic policies and monitor their own progress.

As the MDGs aim to reverse the growing tide of world poverty, developing countries are expected to be active at a national level. At the same time, developed countries have a corresponding obligation o ensure an international environment conducive to development. Therefore, developed countries are to focus on stimulating action on aid, trade, debt relief, new technologies and investment flows. It is therefore understood that developing as well as developed countries will submit annual progress reports, foste ational campaigns and produce country studie national campar strategies.

This section will address the MDG country reporting mechanisms and outlines as set by the UN while showing some of the country/regional studies and strategies submitted by national governments, international organizations and UN agencies. Information has also been made available through countr and regional led MDG campaigns.

The Millennium Development Goals Report (MDGR) is a tool to be utilized for awareness raising, advocacy, alliance building, and renewal of political commitments at the country level. It is also intended to build national capacity for monitoring and reporting on goals and targets. Each signatory country to the Millennium Declaration is expected to produce an MDGR

UN Country Teams (UNCTs) have been ap pointed to support the preparation of the MDC reports in order to ensure that every country uses consistent methodology. UNCTs assist countries to prepare reports in a way that fosters broad nationa ownership. This help includes both consultation an collaboration that involves a variety of stakeholders, as well as relevant UN agencies, governments, civil society organizations, foundations, and the private sector. UNCTs are also commissioned to do som capacity building especially in the area of mationa data collection, analysis and application.

\subsection{Civil society action ${ }^{18}$}

Since the adoption of the Millennium Declaration, civil society organizations (CSOs) have tried to contribute and influence the discourse concerning the Millennium Development Goals. Through this process, the view points stemming from these groups have changed: some have expressed disappointment in the commitment on the part of governments, while others have remained more hopeful as for reaching the Goals by 2015. Whether critical or optimistic, it is clear that the nature of CSO engagement has served to enrich the dialogue and debates surrounding the Millennium Development Goals. In harmony with this spirit, this section will present the reflections, research and campaigns originating from the work of $\mathrm{CSOs}$. The reflections and reserch include CSO commentaries, statements, and citical analysis concernin king framework established for the MDGs, but it also involves some analysis as to the role of civil society organizations in the MDG decision-making process. As for the campaigns, promotional websites are listed and cover both national and international tasks that are organized by CSOs. This offers the possibility for those interested to get directly involved in campaigns, coordinate efforts or just simply learn more about the events happening in different regions across the globe.

In September 2005, over 750 non-governmental organizations (NGOs) - including 1,800 NGO representatives - from all over the world took part in the 57th Annual NGO Conference in New York (7-9 September 2005) organized by the United Nations Department of Information (DPI) in partnership with the NGO/DPI Executive Committee. The purpose of the conference was to give a boost to civil society action towards the Millennium Development Goals through a series of plenary sessions and interactive workshops.

\section{Work of lawyers}

"Lawyers should not be the only voice in human rights and, equally, economists should not be the only voice in development. The challenge now is to demonstrate how the assets represented by human rights principles, a form of international public goods, can be of value in pursuing the overarching development objective, the eradication of poverty." 19

\section{The language Format}

The language is understood to be simple, clear and accessible. Yet, depending on the audience, some terms - such as "gender discrepancy, "environmenal sustainability"... might seem technical for noninitiated readers.

\section{The Length and Format ${ }^{20}$}

The MDGR is above all an advocacy tool that describes developments in reaching the MDGs. This report is not an in-depth analytical review of policy reform, resource allocations and institutional change. Its length and format should be determined in line with this objective. Granted that each goal can be summarized in a spread of 2 pages, the length of MDGRs should normally vary between 20-25 pages. As a result, the format will be short and sharp, concise and light, and will avoid wordy and complex text. will contain simple diagrams ot that key messages and clear, even after a quick glance. merge loud and clear, even after a quick glance. The design of the global monitoring report entitled 'A Better World for All' as well as the first MDGR (for Cameroon, Tanzania and Vietnam) was prepared with this intent and purpose. MDGRs are expected to range somewhat in content and format, reflecting inter alia national development priorities and data availability.

\section{Common List of Goals ${ }^{21}$}

The common list of 8 goals, 18 targets and 40+ indicators prepared by the UN, the World Bank, IMF and OECD will provide a common assessment and un derstanding of the status of MDGs at global, regional and national levels ${ }^{22}$. As the targets and indicators are based on the results of the world summits and global conferences, they are very similar to the cursimilar to the curpart, the International Development Goals.

There are some goals and targets that cannot be monitored at the country level. Just to mention one example, Goal 8 on a Global Partnership for Development, can only be monitored at the global level.

The MDGR will take into consideration nationa development priorities, which means that the MDGs will need to be defined within the country-specific situation tnotherwords, the globalgoals should be adapted into nation 
the approval of national stakeholders. Thus, each country will have to decide on one or more among the following three choices: (1) select those goals and targets as agreed at the global level; (2) select the tarpe appropriate goals and argets butapt them to the country circumstances; and (3) add other goals and
targets that are relevant to the country.

For instance, the global target of reducing underfive mortality by two-thirds between 1990 and 2015 seems impossible in countries that are severely affected by HIV/AIDS or by the spread of malaria. Different targets for child mortality will have to be set in these countries. Countries may also wish to set in the cor define nom ,Ifothers match Europe's increased aid, and trade and development initiatives; if we can support a successful conclusion to the Doha Development Round of world trade negotiations; if developing countries deliver on their side of the bargain; then If firmly believe that achieving the Millennium Development Goals will be within our grasp." ${ }^{23}$ (H.E. Mr. José Manuel BARROSO President of the European Commission)

6. Introduction of each goal

6.1 Goal 1: Eradicate Hunger and Extreme Poverty $^{24}$

"Poverty is pain; it feels like a disease. It attacks a person not only materially but also morally. It eats away one's dignity and drives one into total despair." ${ }^{123}$

The world today is more prosperous than it has ever been before. The technological advances of recent years have generated encouraging new opportunities to improve economies and reduce hunger.

It is estimated that 1.2 billion people have to survive on less than US\$1 a day, 800 million are undernourished and 153 million children under age five are underweight in the developing world. Creating opportunities for all members of a community to influporture ence and cont ibution the reduction a central role in activities seling to the reduction of poverty and the improvement of the human condtion. Working primarily at community level with range of development partners, the UN Volunteers (UNV) programmer concentrates on activities aimed at strengthening local capacity, fostering ownership and participation, and building on existing forms of voluntary action as a catalyst for social and economic de key components for nomic development - all

The Target of Goal 1 of the MDGs to reach by the year The Target of Goal 1 of the MDGs to reach by the year
015 . To reduce by $50 \%$ the proportion of people 2015 . To reduce by $50 \%$ the proportion of people
living on less than a dollar a day. To reduce by $50 \%$

the proportion of people who suffer from hunger. What can we done? For instance, technical support has to be extended to public institutions in poverty mapping and analysis. Assistance in the organization and coordination of hunger prevention and mitigation plans is also needed. Moreover, technical assistance has to be provided which is aimed at easisting local productive systems and incomeenharing such as household agriculture, generating activities, such as sysemsenter informal sector and rural off-farm activities. It is also important to train farmers to use the Internet and other information and telecommunications technology (ICT), accessing weather forecasts, commodity prices for crops and agricultural by-products and to market their own produce. Community groups have to prioritize needs and engage in development initiatives. Community-based organizations ( $\mathrm{CBO}$ ) and non-governm (NCOs) have and nover to be encouraged and supported to become providers of development resources such as microfinance and extension services, especially in remote areas. In addition, local groups, such as associations of cooperatives of farmers, fishermen and cattlemen have to be empowered to share good practices on production methods, natural resource managemen and disease control. Finally, field visits and docuand disess be promoted, just as loca to be promoted, just as local initiatives taken in the
fight against poverty and hunger. ${ }^{26}$ 6.2 Goal 2: Achieve universal primary education ${ }^{27}$ "I want to learn to read and write, get good work, so that I can send my children to a good school, so that they will be able to get good work."28

Every human being should be given the opportunity to make a better life for himself or herself. Unfortunately, many children in the world today grow up in the lack of this chance, because they are denied their basic right to even attend primary school. A sustainable end to world poverty as we know it, as well as the way to peace and security, require that citizens in every country are empowered to make positive choices and provide for themselves and their families. This can only be achieved if all the children of the world can only be achieved if all the chidren of the world have the chance to learn in a high-quality school.

environment at least through primary school.
Worldwide, an estimated 114 million children of Worldwide, an estimated 114 million children of
primary school age are still not enrolled in school, primary school age are still not enrolled in school, thus depriving one in every five children access to even the most basic education. At community level, the UN Volunteers (UNV) programme works in partnership with local volunteer-involving organizations such as parent-teacher associations to address issues connected with enrollment, school dropouts and low literacy rates. In cooperation with other development partners, UNV also helps strengthen the capacity of institutions, teachers and other professionals to render effective educational services.

The Target of Goal 2 of the Millennium Developmen Goals reaches by the year 2015. Ensure that every boy and girl complete a full course of primary schooling. And what can we do? First of all, technical support has to be provided in analyzing socio-economic obstacles to progress in the field of education and strategies have to be der to address them. The the development of innovative curricula adapted to local realities and needs has to be supported as well. Moreover, schools and communities need to be assisted to define and implement programmers which promote girls' education. It is also importan to facilitate the training of trainers at various levels of the education system, as well as to promote the potential of the syternet and other information and potic those in remote areas. VIOs have to be supported in mobilizing young people to assist in expanding and improving educational services and infrastructure in disadvantaged areas. In addition, it is also essential to assist in the creation of parent-teacher associations to ensure communication between the family and school, which in turn promotes educational initiatives. Community-based and nongovernmental organizations have to be encouraged to provide access to literacy courses and practical skills training for out-of-school and dropout children. Then it is also useful to connect local parent-teache associations and community groups with national and international networks to stimulate innovative approaches to education, especially with respect to girls' education. Finally, contacts have to be facilitated among VIOs involved in education to increase their effectiveness.

\subsection{MDG 3: Promote gender equality and} empower women ${ }^{29}$

"When we came here, we could not write or read anything we sat in circles like stones and hardly made any respons. Now we know how to read and write letters, we are aware

of our rights and needs."

Poverty has got a woman's face. Global prosperity and peace will only be achieved if all the world's people are empowered to manage their own lives and provide for themselves and their families. Societies, where women get equal, have a much greate chance of achieving the Millennium Goals by 2015, Every single Goal is directly connected with women's rights, and societies where women are not given equal rights with men can never achieve develop- ment in a sustainable manner. In Africa, Asia, and Latin America, where women have been given the chance to succeed through small business loans or increased educational opportunities, economies are stronger, families are stronger, and societies are flourishing.

Women play a vital role in family and social cohesion and are engaged in a wide range of economic activities. Their voluntary and collective engagement in development represents a formidable "let's go - anyway I $m$ having lunch with Jeremy - want to joins tion. The UN Volunteers (UNV) programmer uses its outreach capacity and its proximity to volunteerinvolving organizations and their networks to help to tap the huge potential of women for social change and development. It further provides practical support to women's groups in different areas, such as literacy, effective management, micro-credit, financial systems, and income generation.

The Target of Goal 3 of the Millennium Development Goals to reach by the year 2015. To eliminate gender disparity in primary and secondary education preferably by 2005, and at each level by 2015. And what can be done? First of all, development institutions need assistance to map and collect data on gender disparities. Moreover, the capacity of institutions has to be developed to properly use gender specific data at local and national levels. In addition, technical support has to be provided to programmers targeting single mothers. It is also essential to promote the potential of the Internet and other information and communications technology (ICT) as a library of information and research tools, to raise awareness. National initiatives need assistance promoting female education. Moreover, help has to be provided to local groups advocate for compulsory education for girls as well as boys. Initiatives have to be supported in connection with protecting female teenagers, including setting age limits for marriages. It is also important to assist VIOs' advocacy efforts for greater gender balance in key institutions such as parliaments. In addition, gender-focused VIOs have to be trained in intensive use of information and communications technology for advocacy work. Help has to be provided to expand national and international networks of gender-promoting VIOs. Finally, it is important to facilitate the exposure of gender-oriented VIOs to innovative approaches on gender equality by likeminded organizations.

\subsection{Goal 4: Reduce Child Mortality}

"The boy died of measles. We all know he could have been cured at the hospital. But the parents had no money, and so the boy died a slow and painful death."132 
One of the darkest features of poverty is that is seems to prey on the vulnerable and defenseless. In low income countries, one out of every 10 children dies before reaching the age of five. In wealthier nations, this ratio is only one out of 143 .

Every year, nearly 11 million children die before reaching their fifth birthday, well over 1,200 every hour of every day. Actually all of the fatalities (99 percent) occur in poor countries, mainly from preventable or treatable illnesses. Working primarily at local level with a range of development partners, the UN Volunteers (UNV) programmer supports activities aimed at the successful promotion of public health care policy, strengthening institutional capacity for effective service delivery, raising awareness on critical health issues and fostering community participation and ownership.

The Target of Goal 4 of the Millennium Development Goals to reach by the year 2015. To reduce the mortality rate by two thirds among children under the age of five. And what can be done? First of all, the accessibility to medical care has to be expanded using innovative approaches such as mobile medical units. Development partners need support in public awareness campaigns. Moreover, vital human resource gaps have to be filled such as having physician during childbirth Local human resources have to be mobilized in response to national public health issues. In addition, local practitioners need training to use the Internet and other information and communications technology (ICT) for the timely distribution of information regarding outbreaks and treatment alternatives. It is also important to train local health care givers to raise effectivenes in service delivery. Help is needed to set up loca health committees to promote village health centers and pharmacies. Moreover, community initiatives that are critical for health improvements have to be supported. It is essential to mobilize volunteer support for health campaigns in such fields a immunization. Help has to be provided to NGO connected with development resources to clean disease-breeding places (rain canals, gutters, waste collection points). In addition, public health awareness has to be raised through the networks of VIOs. Networks have to be supported to cultivate an exchange of information and experiences. Finally, assistance is needed in creating health-related hotlines through VIO networks.

6.5 MDG 5: Improve Maternal Health ${ }^{33}$

"I am going to the sea to fetch a new baby, but the journey

is long and dangerous, and I may not return. ${ }^{34}$
Many people consider it the happiest day in their life when their child is born. In the world's wealthier countries, that is really so. In poorer countries the day when a child is born is all too often the day when the mother dies. In high-fertility countries of sub-Saharan Africa, women have a one in 16 chance of dying in childbirth. In low-fertility countries of Europe, this number is one in 2,000 and in North America it's one in 3,500 .

Globally, more than 500,000 women die in pregnancy or childbirth every year. In the developing world, the risk of dying in childbirth is one in 48 even though virtually every country now has safe motherhood programmers. Working primarily at local level with a range of development partners, the UN Volunteers (UNV) programmer supports activities aimed at the successful promotion of public health care policy, strengthening institutiona capacow on critical health issues and fostering community articipation and ownership.

The Target of Goal 5 of the Millennium Development Goals to reach by the year 2015. To reduce by three quarters the maternal mortality ratio. And what can be done? First of all, the accessibility to medical care using innovative approaches such as mobile medical units needs to be expanded. Support has to be wareness campaigns. Moreover, vital human resource gap have to be filled such as having a physician attend during childbirth. Local human resources have to mobilize in response to national public health issues. In addition, local practitioners need training to use the Internet and other information and communications technology (ICT) for the timely distribution f information regarding outbreaks and treatment . care givers to raise effectiveness in service delivery. Help is needed to set up local health committees to promote village health centers and pharmacies. Moreover, community initiatives that are critical for health improvements have to be supported. It is essential to mobilize volunteer support for health campaigns in such fields as immunization. In addition, pre and post partum examinations by medical professionals including midwives have to be furthered. Public health awareness has to be promoted through the networks of VIOs. It is also essential to support networks of people with the aim of sharing and to assist in creating health-related hotline through VIO networks. Finally, it is important to lobby national and regional governments to implement new legislation to sufficiently finance, staff, and equip medical treatment centers. 6.6 Goal 6: Combat HIV/AIDS, Malaria, and other

"I do not want to make this world more crowded, and I do not want my life to get poorer."

Malaria, together with HIV/AIDS and TB, is one of the major public health challenges that undermine development in the poorest countries in the world. Malaria kills two African children every second. Many children who survive an infection of severe Many children who survive an infection of severe
malaria may suffer from learning impairments malaria may suffer from learning impairments or
brain damage. Pregnant women and their unborn brain damage. Pregnant women and their unborn
children are especially vulnerable to malaria, which is a major cause of prenatal mortality, maternal anemia and low birth weight.

HIV/AIDS is the main cause of death in subSaharan Africa and number four worldwide. Even so, countries such as Brazil, Senegal, Thailand and Uganda have shown that the spread of HIV/AIDS and other major diseases can be stopped. Working primarily at local level with a range of development partners, the UN Volunteers (UNV) programmer supports activities aimed at the successful promotion of public health care policy, fostering community participation and ownership, strengthening insttutional capacity for effective service delivery, and raising awareness on critical health issues.

The Targets of Goal 6 of the Millennium Development Goals to reach by the year 2015. To halt and begin to reverse the spread of HIV/AIDS. To halt and begin to reverse the incidence of malaria and other major diseases. And what can be done? First of all, the accessibility to medical care using innovative approaches such as mobile medical units needs to be expanded. Support has to be given to development partners in preventing and mitigating epidemics. Moreover vital human resource gaps caused by epidemic such as HIV/AIDS have to be filled. Local huma resources have be mobilized in response to nationa public health issues. In addition, local health care givers need training to raise the effectiveness of service delivery. Training is also needed about the use of information and communication technology (ICT) for effective distribution of information about diseases such as HIV/AIDS, tuberculosis and ans. It is important to help set up local heand malaria. It is important to help set up local health committees to promote village health centers and pharmacies. Moreover, support has to be provided to local community-based organizations (CBOs) to launch community initiatives crucial for health improvements. It is essential to mobilize volunteer suppor for health campaigns. CBOs and non-governmenta organizations (NCOs) need help to connet with development resources to support local health pro- motion initiatives. Public health awareness has to be promoted through the networks of VIOs. It is also important to support networks of people living with HIV/AIDS with the aim of sharing experience about, and knowledge of the epidemic. Finally, assiston is needed to create health-related hotlines through VIO networks.

6.7 Goal 7: Ensure environmental sustainability ${ }^{37}$ "We should live here on Earth as though we were intending to stay for good." ${ }^{\prime 38}$

${ }^{39}$ In September 2000, 189 Heads of State adopted the Millennium Development Goals (MDGs), set ting clear, time-bound targets in order to make real progress on the most pressing development issues we have to face. Achieving these targets will directly ffect the lives and future prospects of billions of people all over the globe. It will also set the world on a positive course at the beginning of the 21st century. MDG 7 is to ensure environmental sustainability. One of its targets is as follows. To halve the proportion of people without sustainable ac safe drinking water and basic saitation by 2015 .

Although the MDGs wer for the baseline for most of the MDG targed, in 2000 that on watre most of the MDG targets, including 1990. 19. can be considered the halfway mark owards achieving the 2015 MDG deadline.

The report, prepared by the WHO/UNICEF Joint Monitoring Programme (JMP), provides coverage data for 1990 and 2002 at national, regional and global levels and an analysis of trends towards 2015 as well. It also marks a new cycle of more frequent reporting, that can be effectively used for sector capacity-building efforts at the national and sub national levels. The report is intended to be a 'reality check' for individual countries and the international community on how far we have come, and where we need to focus next, in order to fulfill our commitment.

More than one billion people do not have access to safe drinking water and nearly two billion people lack access to proper sanitation services. In cooperation with development partners and working closely with communities and municipalities, the UN Volunteers (UNV) programmer helps strengthen local capacity to ensure the sustainable use of, and equitable access to natural resources. UNV also provides technical expertise in water and sanitation, supports efforts to generate income in an environmentally sustainn environmentalawareness campaignsand educh as programmers as well.

Targets of Goal 7 of the Millennium Development Goals to reach by the year 2015. To integrate the princi- 
ples of sustainable development into country policie and programmes; and to reverse loss of environmental resources. To reduce by half the proportion of people lacking sustainable access to safe drinkin water. To make significant improvement in lives of at least 100 million slum dwellers, by 2020. In our world today around 2.5 billion people do not have access to improved sanitation and about 1.2 billion people do not have access to an improved source of water. The world now has the financil resources water. The world now has the fin rity and ecources and know-how to increase properity and economic productivity while protecting our natural endowments. But it is only the political will that is lacking to change the status quo. And what can be done? First of all, training has to be provided for municipalities in natural resources management - water, land, forests, etc. Moreover, technical support has to be extended to sustainable water and sanitation programmes. It is also important to strengthen local capacity to It is a so inportant to strer ensure equitable access to natural resource through on-the-job training. Local administration official need training in land tenure and ownership right of poor people. In addition, it is essential to facilitate continuous dialogue on the management of loca natural resources. Help has to be provided for the supervision by VIOs to ensure the sustainable use of environmental resources. The participation of VIOs and local user associations in natural resources manament tives that address entitlements of the poor to secure housing have to be encouraged. It is also importan to develop VIOs' capacity to use information and communications technology (ICT) for advocacy purposes and resource mobilization. Moreover, is essential to facilitate access of national networks of environmental VIOs to the environmental policy and programming decision-making process. Finally, cxill exchanges of experiences, knowledge and skill needs to be stimulated and supported among envronmental VIOs at local, national and internatio levels, especially through a greater use of ICT.

\subsection{MDG 8: Develop global partnerships fo} development ${ }^{40}$

In encouraging global partnerships for development the UN Volunteers (UNV) programme works with private sector companies in the south to help launch business-community programmes targeting grassroots communities. UNV also actively encourage and supports corporate volunteering through whic private sector companies extend the services of their employees, free of charge, to community-focuse development initiatives

Target of this MDG is to develop an open, nondiscriminatory trading and financial system that deals comprehensively with the debt of developing nations. And what can be done? First of all, technical assistance has to be extended to emerging private companies in the South. It is important to facilitate placement of company staff in development programmes. Moreover, a corporate volunteering methodology needs to be designed to serve as a reference for interested companies. In addition, companies need help in setting up business ventures with the local community. Support has to be provided to companies in creating corporate volunteering schemes. It is also essential to develop capacity of businesses in the south for web-based marketing and e-commerce. Moreover, dialogue between the business community and volunteer, communitybased and non-governmental organizations at the local level has to be promoted. It is important to encourage volunteering-involving organizations to mobilize local volunteers to enhance good corporate (apacity of corporate volunteering schemes need help to develop. Then business-community partnerships for local participants have to be furthered. It is also essential to communicate good practices to both civil society and companies to enhance corporate partnerships for local development. Moreover, it is important to bolster networks of corporate solidarity to support the development of an emerging private sector throughout the South. Finally, it is needed to cultivate networks of companies involved in corporate volunteering and business-community relations for cross-fertilization of experiences and advocacy purposes.

Achieving the Millennium Development Goals. "The world is making progress toward the MDGs but it is uneven and too slow. A large majority of nations will reach the MDGs only if they get substantial support - advocacy, expertise and resources - from outside. The challenges for the global community, in both the developed and developing world, are to mobilize financial support and political will, re-engage governments, re-orient development priorities and policies, build capacity and reach out to partners in civil society and the private sector ${ }^{\prime \prime 4}$

Achieving the Millennium Development Goals (MDGs) will require the creativity, ingenuity and solidarity of millions of ordinary people through voluntary action. Efforts of oriony people through volare supported by the international community, can only complement what ultimately will depend on the full involvement of people worldwide. Six billion people have something to contribute. Recognizing this fact can be the first step towards harnessing this vast resource in a global effort to meet the MDG targets. ${ }^{42}$

Achieving these goals would help at least 500 million people to lift out of poverty. Fewer women would die in childbirth, children would go to school, people wouldn't die from treatable diseases, and the lives of millions of people would improve significantly. ${ }^{43}$

7. Epilogue

"The world is making progress toward the MDGs but it is uneven and too slow. A large majority of nations will reach the MDGs only if they get substantial support advocacy, expertise and resources - from outside. The challenges for the global conn challenges for the global conne and developing word, cor to political will, re-engage governments, re-orient development priorities and policies, build capacity and reach ou to partners in civil society and the private sector". (United Nations Secretary-General Kofi A. Annan) The MDGs are a minimum set of goals and standards that need to be tailored to local realities. Global commitments must be taken down to the national and local level if we want them to become a reality. Also, Civil Society Organizations have to play a central role in this transmission and empowering process. If achieving the MDGs within the set timeframe of 2015 seems to be an impossible and unrealistic target for many, we till-or only, it dependson the point of view - have still - or only, it depends on the point of view - have 4 years to go to join forces and attain as many of the goals as possible, if not all. Then a better world may
well be possible. ${ }^{44}$

ANNEX I

\begin{tabular}{|c|c|}
\hline Millennium Development Goals (MDGs) ${ }^{45}$ & \\
\hline Goals and Targets & Indicators \\
\hline \multicolumn{2}{|l|}{ Goal 1: Eradicate extreme poverty and hunger } \\
\hline $\begin{array}{l}\text { Target 1: Halve, between } 1990 \text { and } 2015 \text {, the proportion of } \\
\text { people whose income is less than one dollar a day }\end{array}$ & $\begin{array}{l}\text { 1. Proportion of population below } \$ 1 \text { per day (PPP-values) } \\
\text { 2. Poverty gap ratio [incidence } x \text { depth of poverty] } \\
\text { 3. Share of poorest quintile in national consumption }\end{array}$ \\
\hline $\begin{array}{l}\text { Target 2: Halve, between } 1990 \text { and 2015, the proportion of } \\
\text { people who suffer from hunger }\end{array}$ & $\begin{array}{l}\text { 4. Prevalence of underweight children (under-five years of } \\
\text { age) } \\
\text { 5. Proportion of population below minimum level of dietary } \\
\text { energy consumption }\end{array}$ \\
\hline \multicolumn{2}{|l|}{ Goal 2: Achieve universal primary education } \\
\hline $\begin{array}{l}\text { Target 3: Ensure that, by 2015, children everywhere, boys } \\
\text { and girls alike, will be able to complete a full course of } \\
\text { primary schooling }\end{array}$ & $\begin{array}{l}\text { 6. Net enrolment ratio in primary education } \\
\text { 7. Proportion of pupils starting grade } 1 \text { who reach grade } 5 \\
\text { 8. Literacy rate of } 15-24 \text { year olds }\end{array}$ \\
\hline \multicolumn{2}{|l|}{ Goal 3: Promote gender equality and empower women } \\
\hline $\begin{array}{l}\text { Target 4: Eliminate gender disparity in primary and } \\
\text { secondary education preferably by } 2005 \text { and to all levels of } \\
\text { education no later than } 2015\end{array}$ & $\begin{array}{l}\text { 9. Ratio of girls to boys in primary, secondary and tertiary } \\
\text { education } \\
\text { 10. Ratio of literate females to males of } 15-24 \text { year olds } \\
\text { 11. Share of women in wage employment in the non- } \\
\text { agricultural sector } \\
\text { 12. Proportion of seats held by women in national parliament }\end{array}$ \\
\hline \multicolumn{2}{|l|}{ Goal 4: Reduce child mortality } \\
\hline $\begin{array}{l}\text { Target 5: Reduce by two-thirds, between } 1990 \text { and 2015, the } \\
\text { under-five mortality rate }\end{array}$ & $\begin{array}{l}\text { 13. Under-five mortality rate } \\
\text { 14. Infant mortality rate } \\
\text { 15. Proportion of } 1 \text { year old children immunized against } \\
\text { measles }\end{array}$ \\
\hline \multicolumn{2}{|l|}{ Goal 5: Improve maternal health } \\
\hline $\begin{array}{l}\text { Target 6: Reduce by three-quarters, between } 1990 \text { and 2015, } \\
\text { the maternal mortality ratio }\end{array}$ & $\begin{array}{l}\text { 16. Maternal mortality ratio } \\
\text { 17. Proportion of births attended by skilled health personnel }\end{array}$ \\
\hline \multicolumn{2}{|l|}{ Goal 6: Combat HIV/AIDS, malaria and other diseases } \\
\hline $\begin{array}{l}\text { Target 7: Have halted by 2015, and begun to reverse, the } \\
\text { spread of HIV/AIDS }\end{array}$ & $\begin{array}{l}\text { 18. HIV prevalence among } 15-24 \text { year old pregnant women } \\
\text { 19. Contraceptive prevalence rate } \\
\text { 20. Number of children orphaned by HIV/AIDS }\end{array}$ \\
\hline $\begin{array}{l}\text { Target 8: Have halted by 2015, and begun to reverse, the } \\
\text { incidence of malaria and other major diseases }\end{array}$ & $\begin{array}{l}\text { 21. Prevalence and death rates associated with malaria } \\
\text { 22. Proportion of population in malaria risk areas using } \\
\text { effective malaria prevention and treatment measures } \\
\text { 23. Prevalence and death rates associated with tuberculosis } \\
\text { 24. Proportion of TB cases detected and cured under DOTS } \\
\text { (Directly Observed Treatment Short Course) }\end{array}$ \\
\hline
\end{tabular}


Goal 7: Ensure environmental sustainability ${ }^{46}$

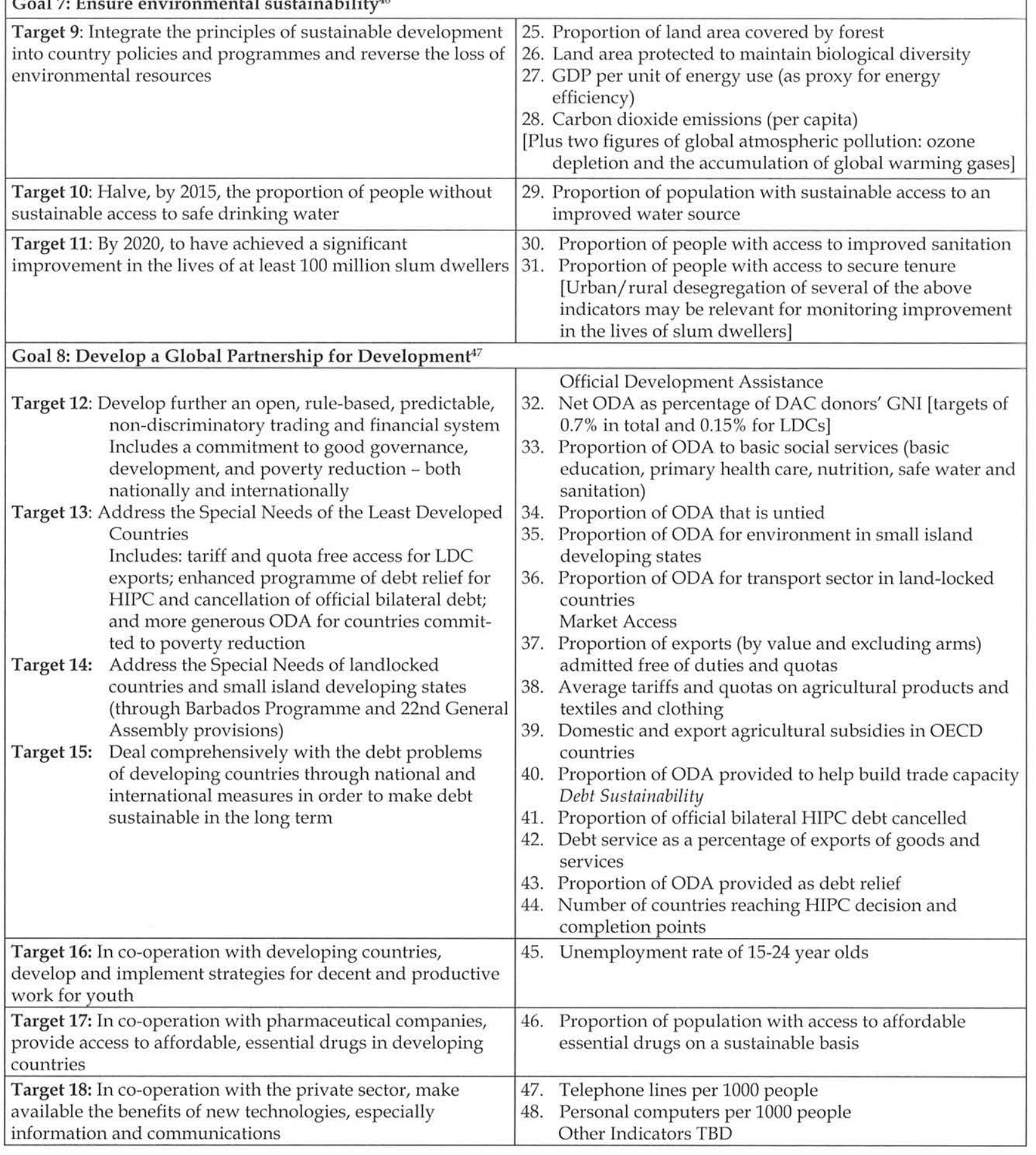

Notes

http:// www.unmillenniumproject.org/press/worldsummit05.htm (23.08.2011.)

${ }^{2}$ http:// www.bbc.co.uk/worldservice/trust/2015/ $3 \mathrm{http} /$ / www bbc.co.uk/worldservice/specials/1112 $\mathrm{mdg} /(23.08 .2011$.)

${ }^{4}$ http://www.ngocongo.org/mdg.htm (24.08.2011.) ${ }^{5}$ Reporting on the Millennium Development Goals at the Country Level; MDGR Guidance Note, October 2001

http:// www.earthinstitute.columbia.edu/ (24.08.2011.) Cosing Plenary Remarks at the Conference on Re Shetty Director, Millennium Campaign United Nations; September 2004
8 Reporting on the Millennium Development Goals at the Country Level; MDGR Guidance Note, October 2001 ${ }^{9}$ http:// www.unhchr.ch/development/mdg.htm (10.01.2006.) http://www.developmenteducation.ie/media/ documents/MDGleaflet.pdf (24.08.2011)

${ }^{10} \mathrm{http} / / /$ www.unmillenniumproject.org/press/worldmit05.htm (23.08.2011.) lennium Development Goals (http://www.un.org/millen$12 \mathrm{http} / /$ / www.be
${ }_{1}$

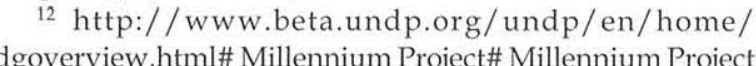
(25.08.2011.) paris21.org/sites/default/files/bwa_e.pdf (24.08.2011.)

${ }^{11}$ MDG Targets and Indicators, United Nations Mil-
${ }^{13} \mathrm{http}$ ://www.beta.undp.org/undp/en/home/ mdgoverview.html\# Millennium Campaign\# Millennium Campaign (25.08.2011.)

$14 \mathrm{http}: / /$ www.beta.undp.org/undp/en/home/
(a) mdgoverview.html\# im

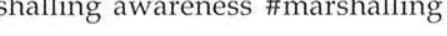
$15 \mathrm{http} / / /$ www.beta.undp.org/undp/en/home/ 16
16
http:// www.ngocongo.org/mdg.htm (25.08.2011)

http:// www.ngocongo.org/mdg.htm (25.08.2011.)
http://www.un-ngls.org/MDG/civilsocietyaction. htm (25.08.2011.) http://www.undpingoconference. org/ (10.01.2006.)

${ }_{18}$ http:// www.un-ngls.org/MDG/civilsocietyaction htm (25.08.2011.), http:// www.undpingoconference.org/ $(10.01 .2006$.
19 "Brid

19 "Bridging the Gap between Human Rights and Development", Presidential Lecture, World Bank, December (10.01.2006.), http:/ / www. unhchr.ch/Huridocda/Huridoca. nsf/0/f2d324c8c0f129e6c1256c67003d9dc0/\$FILE/N0257113. pdf (25.08.2011.)

${ }^{20}$ Reporting on the Millennium Development Goals at the Country Level; MDGR Guidance Note, October 2001 www.undp.or.id/mdg/documents/Guidance $\% 2$ for 2 20MDG\%20.peport.pdf (25.08.2011.), www.emro.who (25.08.2011.)

${ }^{21}$ Reporting on the Millennium Development Goals at undp.or.id/mdg/documents/Guidance $\% 20$ for $\% 20 \mathrm{MDG} \% 2$ Report.pdf (25.08.2011.), www.emro.who.int/CAH/media/ word/MDGs_Country_\%20Level.doc (25.08.2011.)

${ }_{22}^{2}$ See ANNEX ${ }^{23} \mathrm{http}: / /$ www.unmillenniumproject.org/press/world-
mmit05.htm (24.08.2011.)

${ }^{24} \mathrm{http}: / /$ www.millenniumcampaign.org/site/ pp.asp?c=grKVL2NLE\&b=185518 (24.08.2011.), www.r4e.org/ http:/ / www.unvolunteers orr / i nfobase/facts/04 05 20DEU MDG_1_ph.htm(10.01.2006.) http://www.unvolunteers.org/inobase/facts/pdf/MDG/MDG\%201_July2005.pdf (10.01.2006.) $25 \mathrm{http}: / /$ www.paris21.org/betterworld/poverty.htm
(24.08.2011.)

${ }^{26}$ www.onlinevolunteering.org (24.08.2011); $\mathrm{htt}$ :// www. ly2005.pdf (10.01.2006)

${ }^{27}$ www.r4e.org/education/downloads/Millennium\%20Goals.pdf (24.08.2011.), http:/ / www.millenniumcampaign.org/site/pp.asp?c=grKVL2NLE\&b=185519 (10.01.2006 http:// www.unvolunteers.org/infobase/facts/pdf/MDG 28 http//www paris21. org/bettew ${ }^{28} \mathrm{http}: / / \mathrm{www}$.paris21.org/betterworld/education.htm

(ittp://www.unvolunteers.org/infobase/facts/pdf/

MDG/MDG\%203_July2005.pdf (10.01.2006)

${ }^{30} \mathrm{http}: / /$ www.paris21.org/sites/default/files/betterworld-pressrelease.pdf (24.08.2011.)

http://www.paris21.org/sites/default/files/bwa_e.pd $\mathrm{rg} /$ betterworld/gender

${ }^{31} \mathrm{http}: / / \mathrm{www}$.unvolunteers.org/infobase/
facts/pdf/MDG/MDG\%202_July2005.pdf (10.01.2006) http:// www.millenniumcampaign.org/site/ pp.asp?c=grKVL2NLE\&b=186384, (10.01.2006), http:// webcache.googleusercontent.com/search?q=cache:vryECAo2 zMJ:everything.explained.at/child_mortality/+http://www. millenniumcampaign.org/site/pp.asp\%3Fc\%3DgrKVL2NLE
32 http://www.paris21.org/betterworld/infant. htm (10.01.2006), http://journals.tums.ac.ir/upload_files/ pdf/14510.pdf(01.09.2011.)

${ }^{33}$ http://www.unvolunteers.org/infobase/facts/pdf/ MDG/MDG\%202_July2005.pdf (10.01.2006)

http:// www.millenniumcampaign.org/site/ pp.asp?c=grKVL2NLE\&b=186385m (10.01.2006) www.earcos. org/gin2008/download/MilleniumGoals.doc (01.09.2011) ${ }^{4}$ http:/ / www.paris21.org/betterworld/maternal.htm (10.01.2006) http:// w w
cles.html(01.09.2011)

${ }_{35}$ http:// www.millenniumcampaign.org/site/ pp.asp?c=grKVL2NLE\&b=186386 (10.01.2006)

WCM/EDUCATION/assets/portal/Secure/Community/502/ Unit.pdf (01.09.2011)

http:// www.unvolunteers.org/infobase/facts/pdf/ MDG/MDG\%202_July2005.pdf (10.01.2006)

${ }^{36} \mathrm{http}: / /$ www.paris21.org/betterworld/repro.htm (01.09.2011)

http://www.c-fam.org/docLib/20090904_IORG_W_Pa${ }_{37} \mathrm{http} / /$ / www. unvolu

${ }^{37}$ http:// wWw.unvolunteers.org/infobase/facts/ (01.09.1011.)

MDG/MDG\%202_July2005.pdf (10.01.2006)

inter//www.paris21.org/betterworld/environ. htm (10.01.2066), http://www4.gu.edu.au/ext/unesco/ theme_a/mod02/

${ }_{39}$ http:// /www.unicef.org/wes/mdgreport/purpose. php (10.01.206), http:// www.wvi.org/ wvi/wviweb.nst/272 pdf (01.09.2011)

$40 \mathrm{http}$ / / unvolunteers org/infobase/ facts/04_05_20DEU_MDG_general.htm (01.09.2011), http://www.unvolunteers.org/infobase/facts/pdf/MDG/ MDG\%202_July2005.pdf (10.01.2006), http:// unvolunteers. org/infobase/facts/04_05_20DEU_MDG_general.htm (01.09.2011), http:// www.millenniumcampaign.org/site/ pp.asp?c=grKVL2NLE\&b=292090 (10.01.2006.), http://
www.athoo.org/downloads/summary_resolutions/2006/ www.athgo.org/downloads/sumn

${ }^{41}$ What the UN General Assembly says about the MDGs http://www bbc.co.uk/worldservice/specials/1146_key_ players/ (01.09.2011)

42 http://www.unvolunteers.org/infobase/ facts/04_05_20DEU_MDG_general.htm (01.09.2011)

${ }^{13}$ http://www.oxfam.org.uk/what_you_can_do/campaign/mdg/why.htm (05.01.2006)

- onsultahe Relationship with the United Nations (CONGO)

Connecting the Global to the Local to Reach the Millen2004

${ }^{45} \mathrm{http}: / /$ www.itu.int/ITU-D/ict/mdg/goals.html

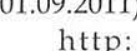

(01.09.2011) $\mathrm{mdgs}$.un.org/unsd/mdg/default.aspx http://ww
$(05.01 .2006)$ http:/ wr

(01.09.2011)
46 The select

The selection of indicators for Coals 7 and 8 is siblot further refinement further refinement 